\title{
Management of Termite (Microtermes adschaggae) on Hot Pepper Using Powdered Leaves and Seeds of Some Plant Species at Bako, Western Ethiopia
}

\author{
Aschalew Sisay ${ }^{*}$, Ahimad Ibrahim ${ }^{1}$ and Tadele Tefera ${ }^{2}$ \\ ${ }^{1}$ Bako Agricultural Research Center, P O Box 03, Bako, Ethiopia \\ ${ }^{2}$ Haramaya University, Department of Plant Sciences, P O Box 42, Ethiopia
}

\begin{abstract}
A study was conducted to evaluate the field efficacy of eleven pesticidal plants against termites on hot pepper at Bako, western Ethiopia during the 2001, 2003 and 2004 cropping seasons. The powdered leaves and seeds of the pesticidal plant species were applied at the rate of $50 \mathrm{~g}$ per $12.6 \mathrm{~m}^{2}$ plot size. In all years, plants with the least termite damage were recorded from plots treated with Maesa lanceolata, Azadirachta indica and the insecticide diazinon $60 \% \mathrm{EC}\left(2.5 \mathrm{lit} \mathrm{ha}^{-1}\right)$. The highest stand count and yield were also obtained from plots treated with the same plant species and diazinon. Treatment with Shinus molle and Ficus vasta appeared to have the lowest effect on termite damage protection. Consequently, there was low plant population at harvest. The use of $M$. lanceolata and $A$. indica should be promoted as part of an integrated management system of termites on hot pepper, particularly by poor farmers.
\end{abstract}

Keywords: Azadirachta indica; Maesa lanceolata; Pepper; Termite

\section{Introduction}

Termites have been regarded as serious insect pests that attack a wide range of agricultural crops, forest trees and buildings in western Ethiopia. Most of the prevailing termite species are Macroterms subhyalinus (Rambur) and Microtermes adschaggae (Sjosted). They are subterranean in nature and only a few species are mound forming and are difficult to locate and destroy. Termite attacks caused up to $62 \%$ and $36 \%$ reduction in yields of hot pepper and maize respectively in the region (Abdurrahaman, 1983; Abraham, 1990; Devendra et al., 1998). This devastating insect pest also causes soil degradation by reducing vegetation and leaving the soil surface barren and exposed to erosion (Abraham, 1990; Devendra et al., 1998). As a result, farmers are forced to abandon their farmlands and migrate to other places (Abraham and Adane, 1995). In addition, the consequences of termite infestation reduced farm productivity, increased land degradation and vulnerability of resource poor farmers (Altieri, 1984; Devendra et al., 1998).

Use of cultural control methods such as mound destruction, removal of the queen, flooding, use of hot ash, are not effective against termites. As a result, termite control methods depend heavily on synthetic chemicals, especially organochlorines such as aldrin (Abdurahaman, 1990). Many plant species have been reported to posses insecticidal and repellent properties against termites; however, only Azadirachta indica and Ipomea fistulosa products have been field-tested. According to Listinger et al. (1978), incorporating such plants and their derivatives into the annual cropping system may provide an ecologically-sound method of termite control. Hence, the present study reports on the field efficacy of some plant products against subterranean termites.

\section{Materials and Methods}

\subsection{Description of the Study Site}

The experiment was conducted at the Bako Agricultural Research Center (BARC), western Ethiopia. The center lies between 9० 6' N latitude and 37॰09' E longitude, 1650 meters above sea level. The mean annual rainfall is 1217 $\mathrm{mm}$ and its pattern is unimodal. The rainy period is from April to October. It has a warm humid climate with mean minimum, mean maximum and annual mean temperatures of $13^{\circ} \mathrm{C}, 28^{\circ} \mathrm{C}$ and $18^{\circ} \mathrm{C}$ respectively (Table 1). Sixty percent of the soil is reddish brown Nitosols with a $\mathrm{pH}$ range of $5.0-5.31$.

Table 1. Total rainfall, temperature, relative humidity at Bako, western Ethiopia during the 2001 and 2003 cropping seasons.

\begin{tabular}{llllll}
\hline Year & \multicolumn{2}{l}{ Total Rainfall $(\mathrm{mm})$} & \multicolumn{2}{l}{ Temperature ${ }^{0} \mathrm{C}$} & Relative Humidity $(\%)$ \\
\hline & & Min. & Max. & Mean & \\
2001 & 1452 & 12.0 & 27.0 & 19.5 & 75.6 \\
2003 & 1041 & 13.8 & 29.0 & 21.4 & 58.6 \\
\hline
\end{tabular}

\subsection{Trial Design and Management}

The experiment was conducted for two years, i.e. during the 2001, 2003 and 2004 cropping seasons. Eleven different species of plants (Table 2) were evaluated, together with the insecticide diazinon 60\% EC and untreated checks to determine their efficacy against the termite Microtermes adschaggae (Sjosted). The experiment was laid out in randomized complete block design
(RCBD) with three replications in 2001 and 2003. The plot size was $4.2 \mathrm{~m}$ long and $3 \mathrm{~m}$ wide, with the intra row spacing of $0.3 \mathrm{~m}$ and inters spacing of $0.70 \mathrm{~m}$. There were eight rows per plot. In 2004, a verification trial with the two most promising plant species, $M$. lanceolata and $A$. indica was conducted on $85 \mathrm{~m}^{2}$ plot size per treatment without replication. Plots treated with diazinon 60\% EC and untreated checks were included. DAP and Urea were

*Corresponding author. E-mail: aschaloosg@yahoo.com 
applied at the rates of $207 \mathrm{~kg} / \mathrm{ha}$ and $137 \mathrm{~kg} / \mathrm{ha}$ respectively. Hand weeding was done three times.

Table 2. List of pesticidal plants evaluated against termite on hot pepper in 2001 and 2003 cropping seasons at Bako, Western Ethiopia.

\begin{tabular}{ll}
\hline Scientific name & Plant part used \\
\hline Maesa lanceolata & Leaf powder \\
Chenopodium sp. & Leaf powder \\
Azadirachta indica & Seed powder \\
Croton macrostachyus & Leaf powder \\
Tagetes minuta & Leaf powder \\
Datura stramonium & Leaf powder \\
Vernonia amygadalina & Leaf powder \\
Phytolacca dodecandra & Leaf powder \\
Nicotiana tobaccum & Leaf powder \\
Shiness molle & Leaf powder \\
Ficus vasta & Leaf powder \\
\hline
\end{tabular}

\subsection{Treatment Application}

The leaves of the selected plant species were collected, dried and ground into fine powders. The powders of the plant species were applied at the rate of $50 \mathrm{gm} / \mathrm{plot}$ as a basal or root application at the transplanting and pod setting growth stages. Likewise, the recommended rate of diazinon $60 \%$ EC (2.5 lit /ha) was applied at the transplanting and pod setting growth stages. Untreated check plots were neither treated with the insecticide nor with leaves and seed powders of plants species.

\subsection{Data Collection and Analysis}

Two weeks after the first treatment application and every two weeks thereafter until physiological maturity, ten plants were randomly sampled per plot to assess for termite-damage. The mean of termite-damaged plants was expressed as a percentage of the total samples. To avoid double counting, tags were placed on sampled plants.
Stand count was taken at harvest. The six middle rows were harvested at physiological maturity. Dry pod yield per plot was converted to $\mathrm{kg} \mathrm{ha}^{-1}$. The percentage of termite-damaged plants and stand counts at harvest were square-root transformed to stabilize the variances. Oneway analysis of variance was used. The data were analyzed using MSTAT and the Least Significant Difference (LSD) was used for mean separation at $P<0.05$. Yield advantage in Table 5, was calculated by comparing the untreated check plots with the treated plots.

\section{Results and Discussion}

In all the years, lower termite-damaged plants were recorded from plots treated with $M$. lanceolata, $A$. indica and diazinon $60 \%$ EC than from the remaining treatments (Tables 3 and 4). The highest stand count and yield were also obtained from plots treated with the same plant species and diazinon $60 \% \mathrm{EC}$. This was further verified in the large area in 2004 (Table 5). Treatment with $S$. mole and F. vasta appeared to have the least effect on termite damage protection. Consequently, there was low plant population at harvest. Aschalew et al. (2005), reported that C. macrostachyus and T. minuta have repellent properties against termites while $D$. stramonium, $F$. vasta, $A$. indica leaves and Chenopodium sp. had shown insecticidal effects. On the other hand, Gold et al. (1991) and Epilla et al. (1988) reported that these plants possess insecticidal, repellent, or antifeedant properties. Several species of plants have been reported as being toxic or repellent to termites. However, only $A$. indica and $I$. fistulosa products have been field-tested. Fekede and Kedir (2004) reported that $M$. lanceolata also had fungicidal properties comparable to the fungicide, thiram, used against sorghum head smut. The fact that these botanicals reduced the damage level of termites might be attributed to their antifeedant, repellant, insecticidal effects or a combination of them.

Table 3. Effect of treatment with leaves and seed powder from different plant species on termite damage, stand count at harvest and dry pod yield of hot pepper at Bako, Western Ethiopia in 2001 cropping season.

\begin{tabular}{llll}
\hline Treatments & Percent damaged plants & Mean stand count at harvest & Dry pod yield kg/ha \\
\hline Maesa lanceolata & $2.8 \pm 1.2^{*} \mathrm{f}$ & $56.0 \pm 1.5 \mathrm{a}$ & $670 \pm 39 \mathrm{a}$ \\
Chenopodium spp. & $10.6 \pm 0.9 \mathrm{cde}$ & $47.0 \pm 0.6 \mathrm{cde}$ & $400 \pm 37 \mathrm{~b}$ \\
Aradiracbta indica & $5.0 \pm 1.2 \mathrm{ef}$ & $54.0 \pm 1.5 \mathrm{ab}$ & $650 \pm 19 \mathrm{a}$ \\
Croton macrostachys & $8.3 \pm 0.6 \mathrm{def}$ & $41.7 \pm 3.3 \mathrm{ef}$ & $420 \pm 66 \mathrm{~b}$ \\
Tagetes minuta & $8.3 \pm 0.6 \mathrm{def}$ & $39.3 \pm 3.7 \mathrm{f}$ & $330 \pm 27 \mathrm{bc}$ \\
Datura stramonium & $10.6 \pm 0.9 \mathrm{cde}$ & $50.3 \pm 1.2 \mathrm{bcd}$ & $350 \pm 99 \mathrm{bc}$ \\
Vernonia amygadalina & $9.4 \pm 1.8 \mathrm{cde}$ & $39.7 \pm 2.2 \mathrm{f}$ & $360 \pm 50 \mathrm{bc}$ \\
Phytolacca dodecandra & $8.9 \pm 1.7 \mathrm{de}$ & $43.7 \pm 0.7 \mathrm{ef}$ & $280 \pm 17 \mathrm{bc}$ \\
Nicotiana tobacum & $15.0 \pm 1.7 \mathrm{bc}$ & $29.0 \pm 0.6 \mathrm{~g}$ & $310 \pm 81 \mathrm{bc}$ \\
Shinus molle & $12.8 \pm 1.6 \mathrm{bcd}$ & $29.7 \pm 0.9 \mathrm{~g}$ & $370 \pm 61 \mathrm{~b}$ \\
Ficus vasta & $16.7 \pm 1.5 \mathrm{~b}$ & $28.0 \pm 3.5 \mathrm{~g}$ & $310 \pm 45 \mathrm{bc}$ \\
Diazinon $60 \%$ EC & $5.6 \pm 1.2 \mathrm{ef}$ & $52.0 \pm 1.0 \mathrm{abc}$ & $580 \pm 17 \mathrm{a}$ \\
Untreated check & $23.9 \pm 0.9 \mathrm{a}$ & $31.6 \pm 3.8 \mathrm{~g}$ & $230 \pm 25 \mathrm{c}$ \\
LSD $(0.05)$ & 5.6 & 5.4 & 1.5 \\
Mean & 10.5 & 40.5 & 4.00 \\
\hline
\end{tabular}

* Means with the same letter in a column are not significantly different at $P<0.05$. 
Table 4. Effect of different pesticidal plants treatment against termite damage, stand count at harvest and dry pod yield (kg/ha) of hot pepper at Bako, Western Ethiopia in 2003 cropping season.

\begin{tabular}{llll}
\hline Treatments & Percent damaged plants & Stand count at harvest & Dry pod yield kg/ha \\
& & & $250 \pm 22 \mathrm{ab}$ \\
Maesa lanceolata & $12.2 \pm 1.3 \mathrm{~g}$ & $52.0 \pm 1.5 \mathrm{a}$ & $170 \pm 44 \mathrm{bcd}$ \\
Chenopodium spp. & $40.0 \pm 2.6 \mathrm{bc}$ & $36.0 \pm 2.6 \mathrm{bcd}$ & $290 \pm 26 \mathrm{a}$ \\
Azadirachta indica & $13.9 \pm 0.8 \mathrm{fg}$ & $51.3 \pm 0.6 \mathrm{a}$ & $190 \pm 38 \mathrm{bcd}$ \\
Croton macrostachys & $26.7 \pm 1.5 \mathrm{de}$ & $39.3 \pm 2.2 \mathrm{bc}$ & $170 \pm 30 \mathrm{cde}$ \\
Tagetes minuta & $25.5 \pm 1.7 \mathrm{de}$ & $36.0 \pm 2.1 \mathrm{bcd}$ & $90 \pm 16 \mathrm{e}$ \\
Datura stramonium & $23.3 \pm 1.0 \mathrm{def}$ & $39.7 \pm 0.3 \mathrm{~b}$ & $190 \pm 20 \mathrm{bcd}$ \\
Vernonia amygadalina & $25.6 \pm 3.7 \mathrm{de}$ & $41.0 \pm 0.6 \mathrm{~b}$ & $190 \pm 14 \mathrm{bcd}$ \\
Phytolacca dodecandra & $38.3 \pm 1.1 \mathrm{bc}$ & $33.3 \pm 2.9 \mathrm{~cd}$ & $140 \pm 21 \mathrm{de}$ \\
Nicotiana tobaccum & $31.7 \pm 2.9 \mathrm{~cd}$ & $36.7 \pm 3.2 \mathrm{bcd}$ & $160 \pm 21 \mathrm{cde}$ \\
Shinus molle & $46.7 \pm 0.6 \mathrm{~b}$ & $32.0 \pm 1.2 \mathrm{~d}$ & $160 \pm 21 \mathrm{cde}$ \\
Ficus vasta & $57.2 \pm 0.5 \mathrm{a}$ & $25.3 \pm 1.1 \mathrm{e}$ & $230 \pm 31 \mathrm{abc}$ \\
Diazinon 60\% EC & $16.7 \pm 1.5 \mathrm{efg}$ & $49.0 \pm 1.5 \mathrm{a}$ & $190 \pm 5 \mathrm{bcd}$ \\
Untreated check & $45.0 \pm 1.3 \mathrm{~b}$ & $33.0 \pm 1.2 \mathrm{~d}$ & 70 \\
LSD $(0.05)$ & 10.1 & 6.3 & 180 \\
Mean & 30.5 & 39.2 & \\
\hline
\end{tabular}

* Means with the same letter in a column are not significantly different at $P<0.05$.

The highest yield of pepper was obtained from treatment with $M$. lanceolata, $A$. indica and diazinon $60 \%$ EC (Tables 3 \& 4). The other treatments, however, did not differ in yields from the untreated check except the treatment with C. macrostachyus and S. mole in 2001. In the 2004 verification trial, yield advantages of 109 to $150 \%$ over the untreated check were recorded in plots treated with $M$. lanceolata and $A$. indica respectively (Table 5). Brown (1962) reported that incorporating such plants and /or their derivatives into the annual cropping system may provide ecologically-sound methods of termite control. Similar findings were reported by Gold et al. (1991), Logan et al. (1999), and Schroth et al. (1992), where $A$. indica and I. fistulosa mulches were found to reduce termite activity for seven weeks and this should be given due consideration in termite control strategies.

Several plant species have been reported as being toxic or repellent to termites. However, only $A$. indica and $I$. fistulosa products have been field-tested (Gold et al., 1971). On the other hand, Gold et al. (1991) reported that $A$. indica and I. fistulosa mulches reduced termite activity for seven weeks after treatment. In conclusion, the use of $M$. lanceolata and $A$. indica should be promoted as part of an integrated management system of termites on pepper, particularly by (resource) poor farmers.

Table 5. Verification trial on the effects of Azadirachta indica and Maesa lanceolata on the percentage of damage, stand count at harvest and dry pod yield (kg/ha) of hot pepper at Bako, Western Ethiopia during the 2004 cropping season.

\begin{tabular}{llll}
\hline Treatments & Percent damaged plants & Stand count at harvest & Yield $\mathrm{kg} / \mathrm{ha}$ \\
\hline Azadirachta indica & 16.38 & 335 & 1382 \\
Maesa lanceolata & 14.64 & 344 & 1654 \\
Diazinon 60\% EC & 14.39 & 345 & 1595 \\
Untreated check & 39.45 & 241 & 662 \\
\hline
\end{tabular}

\section{Acknowledgement}

The authors are grateful to Mr. Negash Geleta and Teshome Bogale for their assistance in data collection. The Oromia Agricultural Research Institute financed this study.

\section{References}

Abdurahaman, A. 1983. Termite control campaign in Wollega. Committee of Ethiopian Entomologists' Newsletter 3(2): 6-7

Abdurahaman, A. 1990. Foraging activity and control of termites in western Ethiopia. A thesis submitted for the degree of Doctor of Philosophy of the University of London and for the Diploma of the Imperial College. Department of Pure and Applied Biology,
Imperial College of Science, Technology and Medicine. SilwoodPark Ascot.

Abraham, T. 1990. Termites: Problems and possible methods of their control in agriculture with reference to the Ethiopian condition. In: Proceeding of the $10^{\text {th }}$ Annual Meeting of the Ethiopian Entomologists (CEE). 7-9 February 1990. Addis Abeba, Ethiopia. pp. 50-74.

Abraham, T. and Adane, K. 1995. The effect of seed dressing with aldrin on termite in maize western Ethiopia. In: Second Proceeding of Crop Protection Society of Ethiopia 26-27 April 1995. Addiss Ababa, Ethiopia. pp.23. 
Altieri, M.A. and Letourneau, D.K.1984. Vegetation diversity and insect pest outbreaks. CRC Critical Review in Plant Sciences 2:131-169.

Aschalew, S., Diriba, G., and Demisse, A. 2005. Termite in Mana-Sibu District of Oromiya. Special Research Report. Ethiopian Agricultural Research Organization. Addis Ababa, Ethiopia.

Brown, K.W. 1962. Termite control Research in Uganda with particular reference to control of attacks in Eucalyptus plantations. Eighth British Common wealth Forestry Conference. Entebbe, Government publication, Uganda Protectorate. pp. 9.

Devendra, G., Ayo- Odongo, J., Kit, V., Lemma, G. and Mulugeta, N. 1998. A Participatory systems analysis of the termite situation in west Wollega, Oromiya Region, Ethiopia .

Epilla, J.S.O. and Ruyooka, D.B.A. 1988. Cultural methods of controlling termite attacks on cassava (Manohot esculanta) with Vitex doniana: A preliminary study. Sociobiology 14: 291-297.
Fekede, A. and Kedir, W. 2004. The effect of some potential botanical plants in the control of sorghum covered smut at Bako, Ethiopia. Crop Protection Society of Ethiopia annual Conference. Program Abstract. 11-12 August, 2004. Addis Ababa, Ethiopia.

Gold, C.S., Wightman, J.A. and Pimbert, M.P. 1991. Effect of mulches on foraging behavior of Microtermes obese and Odontotermes spp. Insect Science and Its Application 12: 297-303.

Listinger, J.A., Price, P. and Herrera, R.T. 1978. Filipino farmer use of plant parts to control rice insect pests. International Rice Research News Letter 3: 15-16.

Logan, J.M.W., Cowie, R.H. and Wood, T.G. 1999. Termite (Isoptera) control in agriculture and forestry by non-chemical methods: A Review. Bulletin of Entomological Research 80:309-330.

Schroth, G., Zech, W. and Heinmann, G. 1992. Mulch decomposition under agro forestry condition in sub humid tropical savanna: Processes and influence of perennial plants. Plant and Soil 147:1-11. 